\title{
Cloning and expression of a Trichinella spiralis putative glutathione S-transferase and its elicited protective immunity against challenge infections
}

Chun Ying Liu, Yan Yan Song, Hua Na Ren, Ge Ge Sun, Ruo Dan Liu, Peng Jiang, Shao Rong Long, Xi Zhang, Zhong Quan Wang* and Jing Cui*

\begin{abstract}
Background: Glutathione-S-transferase (GST) is a widespread multigene family of detoxification enzymes. The vaccination of mice with recombinant GST of $24 \mathrm{kDa}$ from Trichinella spiralis elicited a low immune protection against challenge infection. The objective of this study was to characterize the T. spiralis putative GST gene (TspGST) encoding a $30.8 \mathrm{kDa}$ protein and to evaluate its potential as a candidate antigen for anti-Trichinella vaccine.

Methods: The full-length cDNA sequence of TspGST from T. spiralis muscle larvae (ML) was expressed in E. coli. The enzymatic activity and antigenicity of the rTspGST were identified by spectrophotometry, Western blot, and ELISA. The expression of TspGST at T. spiralis various stages was investigated by RT-PCR and indirect immunofluorescent test (IIFT). Serum level of total lgG, IgG1, and IgG2a antibodies against rTspGST were measured by ELISA. The immune protection produced by vaccination with rTspGST against $T$. spiralis was evaluated.

Results: The sequencing results showed that the CDNA of TspGST was $840 \mathrm{bp}$, and encoded a protein of 279 amino acids, which had a molecular size of $30.8 \mathrm{kDa}$ and a pl of 5.21. Its amino acid sequence shares $37 \%$ similarity with TsGST. The rTspGST protein had enzymatic activity of GST. On Western blot and ELISA analysis, the native TspGST protein with 30. $8 \mathrm{kDa}$ in crude antigens derived from adult worms (AW), newborn larvae (NBL), infective intestinal larvae (IIL) and ML was recognized by anti-rTspGST sera, but the ML ES antigens could be not recognized by anti-rTspGST sera. Expression of TspGST was found in all of T. spiralis various stages (AW, NBL, ML, and IIL). An immunolocalization analysis identified TspGST in different stages (mainly in cuticles) of the nematode. The mice vaccinated with the rTspGST elicited Th2-predominant immune responses, showed a 34.38\% reduction of adult worms and a $43.70 \%$ reduction of muscle larvae.
\end{abstract}

Conclusions: Immunization with rTspGST produced a partial immune protection, and the rTspGST could be regarded as a potential candidate target for an anti-Trichinella vaccine.

Keywords: Trichinella spiralis, Glutathione-S-transferase (GST), Protective immunity, Mice

\footnotetext{
*Correspondence: wangzq2015@126.com; cuij@zzu.edu.cn

Department of Parasitology, School of Basic Medical Sciences, Zhengzhou

University, Zhengzhou 450052, China
} 


\section{Background}

Trichinellosis is a major foodborne parasitic disease resulted from ingesting raw or semi-cooked meat infected with Trichinella infective larvae [1]. Trichinella infection in animals and humans has been recorded in most provinces on the Chinese Mainland, and 15 outbreaks of trichinellosis consisting of 1387 cases and four deaths occurred from 2004 to 2009 [2-4]. Pork is the dominating source of infection for trichinellosis outbreaks in China. Swine Trichinella infection is an important hygiene problem for meat product safety and public health [5]. Therefore, an anti-Trichinella vaccine for domestic pigs has become another promising measure to prevent the transmission of trichinellosis from swine to humans [6-9].

After being ingested, Trichinella spiralis muscle larvae (ML) are released in the stomach with the help of digestive enzymes, migrate to the intestine, and develop into the infective intestinal larvae (IIL) [10]. The IIL penetrate the intestinal epithelium, molt four times, and then develop into adult worms (AW) which copulate and produce newborn larvae (NBL). Since the IIL is the first invasion phase during T. spiralis life-cycle, an anti-Trichinella vaccine against the IIL could potentially prevent the intestinal Trichinella infection, which might block or inhibit the subsequent occurrence of the muscular phase of trichinellosis. Previous studies demonstrated that the $T$. spiralis glutathione-Stransferase (TsGST) gene (GenBank: XM_003371707.1) encoding a $24 \mathrm{kDa}$ protein was an up-regulated gene in the IIL compared with the ML stage [11, 12], suggesting that the TsGST might be a larval invasion-related protease. However, the vaccination of mice with the rTsGST resulted in a $35.71 \%$ reduction of adults in the intestine and a $38.55 \%$ reduction of larvae in muscle, indicating that immunization with the rTsGST elicited a low immune protection against $T$. spiralis infection [13]. In this study, we cloned and expressed a putative $T$. spiralis GST gene (GenBank: XM_003373603) encoding a $30.8 \mathrm{kDa}$ protein [14], the characteristics of TspGST was investigated, and the immune protection generated by the rTspGST immunization was evaluated in mice.

\section{Methods}

\section{Parasites and experimental animals}

The T. spiralis isolate (ISS534) used here was from a domestic pig in the Henan Province of China. It was passaged in Kunming mice at 6-8 month intervals in our laboratory. Female BALB/c mice, specific pathogen-free (SPF) and 46 weeks of age, were obtained from the Henan Provincial Experimental Animal Center (Zhengzhou, China).

\section{Parasite collection and antigen preparation}

The mice were infected orally with $300 \mathrm{~T}$. spiralis ML and euthanized at 42 days post infection (dpi). The carcasses were artificially digested by digestion solution containing
0.33\% pepsin (1:31,000; Sigma-Aldrich, St. Louis, MO, USA) and $1 \% \mathrm{HCl}$ at $43{ }^{\circ} \mathrm{C}$ for $2 \mathrm{~h}$, and then the ML were collected $[15,16]$. The IIL were recovered from small intestines of experimentally infected mice at $6 \mathrm{~h}$ post infection (hpi) [17], and the AW were respectively collected from the duodenum and jejunum of infected mice at 3 and 6 dpi [18]. The NBL was obtained from female worms incubated in RPMI-1640 medium at $37{ }^{\circ} \mathrm{C}$ for $24 \mathrm{~h}$ [19]. The soluble proteins (crude antigens) of AW, NBL, ML and IIL, and excretory-secretory (ES) proteins from the ML were prepared [20, 21].

\section{Cloning, expression, and identification of TspGST}

The TspGST gene (GenBank accession no. XM_003373603) was amplified by PCR using specific primers with BamHI and Hind III restriction enzyme sites (underlined) (forward: 5' -TAT AGG ATC CAT GAC CAA CAC GTC GAA GAA AGG-3'; reverse, 5'-GCC CAA GCT TTC ATT GAC TTT CAA TAG TCA CTG G-3'). The purified PCR product was cloned into the pMD19-T vector (Takara, Dalian, China), subsequently sub-cloned into the pQE-80 L (Novagen, La Jolla, CA, USA). The recombinant plasmid carrying the TspGST gene was transformed into Escherichia coli BL21 (DE3) (Novagen), and expressed under IPTG induction. The rTspGST was purified using Ni-NTA-Sefinose resin (Sangon Biotech, Shanghai, China). The concentration of the purified rTspGST was assayed as described previously [22], and identified by SDS-PAGE analysis [23]. The gel was stained with $0.25 \%$ Coomassie brilliant blue R-250 (Sigma-Aldrich), and subsequently decolorized.

\section{Assay of rTspGST enzymatic activity}

The enzymatic activity of the purified rTspGST was determined spectrophotometrically by observing the production of the thioether (S-2,4-dinitrophenylglutathione) between the reduced form of glutathione and 1-chloro2,4-dinitrobenzene (CDNB; Sigma-Aldrich). The enzymatic product extinction coefficient $\varepsilon=9600 \mathrm{M}^{-1} \mathrm{~cm}^{-1}$ at $25^{\circ} \mathrm{C}$ at $340 \mathrm{~nm}$. The reaction was conducted in $1 \mathrm{ml}$ reaction mixture consisting of $1 \mathrm{mM}$ reduced $\mathrm{GSH}, 7 \mu \mathrm{g}$ of rTspGST, and $100 \mathrm{mM}$ phosphate buffer. The reaction was started by the addition of $1 \mathrm{mM} \mathrm{CDNB}$ as substrates, and the increase in absorbance at $340 \mathrm{~nm}$ was recorded for $5 \mathrm{~min}$ [13]. The rTsGST samples were repeatedly assayed three times, and the results were shown as mean values \pm standard deviation (SD).

\section{Immunization of mice}

The mice were randomly divided into three groups (20 animals per group). The vaccination group of mice was subcutaneously inoculated at multiple abdominal sites with $20 \mu \mathrm{g}$ of rTspGST emulsified with complete Freund's adjuvant and boosted three times with the rTspGST with incomplete Freund's adjuvant at an 
interval of 10 days. Two control groups were inoculated with adjuvant or PBS using the vaccination mentioned above procedure [24]. Tail blood from vaccinated mice was respectively collected at $0,10,20,30$ and 40 days after vaccination.

\section{Determination of antibodies to rTspGST}

Serum anti-rTspGST IgG of vaccinated mice was assayed by ELISA with crude antigens of ML, IIL, AW and NBL, ML ES antigens, or the rTsGST; the IgG subtypes (IgG1 and IgG2a) were also assayed by ELISA with the rTspGST [25]. The plates (Nunc, Roskilde, Denmark) were coated at $4{ }^{\circ} \mathrm{C}$ overnight with $1.5 \mu \mathrm{g} / \mathrm{ml}$ of the rTspGST, and crude antigens of $T$. spirali various stages. The plates were blocked with $200 \mu \mathrm{l}$ of PBSTween 20 (PBST) containing 5\% skimmed milk. Serum samples diluted at 1:100 were added and incubated at $37{ }^{\circ} \mathrm{C}$ for $1 \mathrm{~h}$. HRP-conjugated goat anti-mouse IgG, IgG1 or IgG2a (1:5000; Sigma-Aldrich) were used as the secondary antibodies, and o-phenylenediamine dihydrochloride (OPD; Sigma-Aldrich) was used as a substrate. The absorbance at $490 \mathrm{~nm}$ was assayed with a microplate reader (Tecan, Schweiz, AG, Switzerland).

\section{Western blot analysis}

Proteins included $15 \mu \mathrm{g} / \mathrm{lane}$ of ML crude and ES antigens, and the rTsGST. The proteins were separated by SDS-PAGE at $120 \mathrm{~V}$ for $2.5 \mathrm{~h}$, then transferred onto nitrocellulose membranes (Merck Millipore, Billerica, MA, USA) at $20 \mathrm{~V}$ for $40 \mathrm{~min}$ [26]. The membranes were clipped into strips, blocked by PBST with $5 \%$ skimmed milk at $37{ }^{\circ} \mathrm{C}$ for $1 \mathrm{~h}$, and incubated at $37{ }^{\circ} \mathrm{C}$ for $1 \mathrm{~h}$ with 1:100 dilutions of different mouse sera (anti-rTspGST sera, sera from mice infected $T$. spiralis at $42 \mathrm{dpi}$ and normal mouse sera). After washing, the strips were incubated with HRP-conjugated goat antimouse IgG (Sigma-Aldrich). 3, 3'-diaminobenzidine tetrahydrochloride (DAB; Sigma-Aldrich) was used as the substrate [13].

\section{RT-PCR analysis of TspGST gene transcription}

Total RNA was respectively extracted by using Trizol reagent (Invitrogen, Carlsbad, CA, USA) from T. spiralis various stages (AW at 3 and $6 \mathrm{dpi}, \mathrm{NBL}, \mathrm{ML}$, and IIL). RT-PCR was conducted as described [27]. A housekeeping gene of T. spiralis (glyceraldehyde-3-phosphate dehydrogenase, GAPDH) was also amplified as a positive control. PBS was used as negative control for all PCRs.

\section{Indirect immunofluorescent test (IIFT)}

The IIFT was used to determine the expression and immunolocalization of the native TspGST at $T$. spiralis diverse stages [28]. The whole intact worms and sections of the parasite tissues were blocked in PBS containing 5\% goat sera, reacted with 1:100 dilutions of anti-rTspGST sera, infection sera or normal mouse sera at $37^{\circ} \mathrm{C}$ for $1 \mathrm{~h}$. The FITC-labeled goat anti-mouse IgG (Santa Cruz Biotechnology, Dallas, Texas, USA) diluted at 1:100 was used as the secondary antibodies. After washing, the whole worms and tissue sections were observed with a fluorescent microscope (Olympus, Tokyo, Japan).

\section{Challenge experiment}

Ten days after the last vaccination, each mouse of three groups was challenged orally with $300 \mathrm{~T}$. spiralis ML. Ten mice of each group were sacrificed at $5 \mathrm{dpi}$, and the intestinal AW were recovered and counted $[29,30]$. The ML burdens from the other ten mice of each group were investigated at 42 dpi by artificial digestion $[13,31]$. The immune protection was evaluated as the reduction rate of recovered AW and larvae per gram (LPG) of muscles of the vaccinated groups versus that of the PBS group [32].

\section{Statistical analysis}

The statistical analyses of the data were performed via SPSS for Windows, version 17.0. The data of OD values of antibody levels and the AW and ML recovery were shown as the mean value \pm standard deviation (SD). One-way ANOVA or Student's t-test was utilized for the analysis of intra- and intergroup differences, and $P<0.05$ was regarded as statistically significant.

\section{Results}

Molecular cloning and expression of the cDNA encoding a $30.8 \mathrm{kDa}$ TspGST

The full-length TspGST cDNA was 840 bp and encoded a protein of 279 amino acids, which had a molecular size of $30.8 \mathrm{kDa}$ and a $\mathrm{pI}$ of 5.21. SignalP 4.1 Server predicted that the TspGST did not have signal peptides. The TspGST had only the 37\% identity with TsGST at the amino acid level, which was aligned by protein BLAST. The pQE- $80 \mathrm{~L}$ harboring the TspGST gene was successfully transformed into $E$. coli BL21 (DE3) bacteria. After being induced with $0.5 \mathrm{mM}$ IPTG, recombinant TspGST produced a band of approximately $30.8 \mathrm{kDa}$ protein examined by SDSPAGE, the molecular weight of the rTspGST protein was compatible with its predicted size. On SDS-PAGE analysis, the rTspGST protein purified by Ni-NTASefinose Column showed a clear single band (Fig. 1).

\section{Enzymatic activity of rTspGST}

The enzymatic activity analysis revealed that the enzymatic activity of the rTspGST to conjugate glutathione to CDNB was $115.42 \pm 7.71 \mathrm{U} / \mathrm{mg}$ protein. 


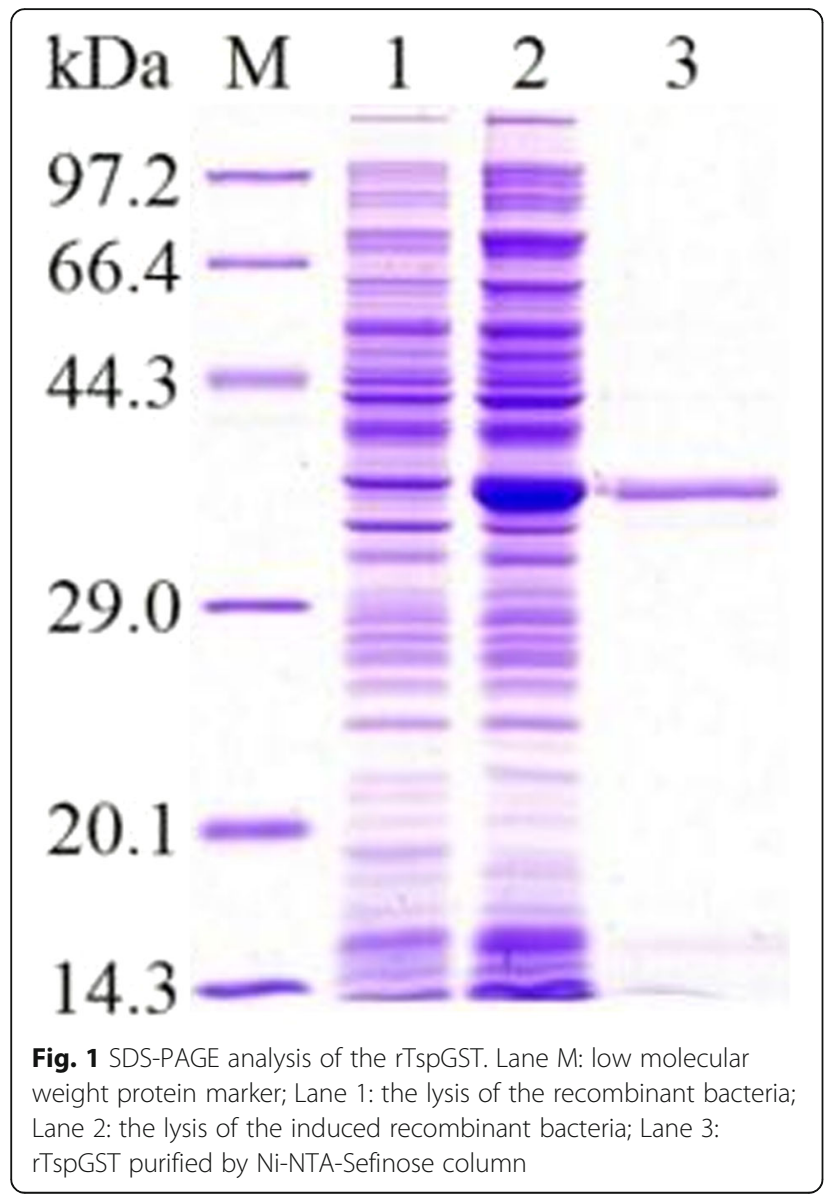

\section{Analysis of rTspGST antigenicity}

The rTspGST was identified by anti-rTspGST serum on Western blot analysis. Anti-rTspGST sera also identified the native TspGST protein in ML crude antigens but did not identify the ML ES antigens. Furthermore, the rTspGST was identified by sera of mice vaccinated with ML crude antigens, but not by sera of mice vaccinated with ML ES antigens (Fig. 2). The results were obtained under the current experimental conditions, and it is possible that the TspGST cannot be detected if the expression of TspGST in ML ES antigens is low. Also, the ELISA results showed anti-rTspGST sera was strongly reacted with the rTspGST, and crude antigens of $T$. spiralis different stages (NBL, AW at 3 and $6 \mathrm{dpi}$, ML and IIL), but anti-rTspGST sera did not react with the ML ES antigens (Fig. 3). These results suggested that TspGST would be one component of the somatic proteins of $T$. spiralis different phases, but not from ML ES proteins, which indicates that TspGST would not be secreted, and did not expose to the immune system during the muscular phase of T. spiralis infection.

\section{RT-PCR analysis of TspGST gene transcription at various stages}

The TspGST gene (840 bp) was amplified by RT-PCR from $T$. spiralis various stages (AW at 3 and $6 \mathrm{dpi}$, NBL, ML and IIL). The housekeeping GAPDH gene was also amplified from all $T$. spiralis developmental stages as a positive control (570 bp) (Fig. 4).
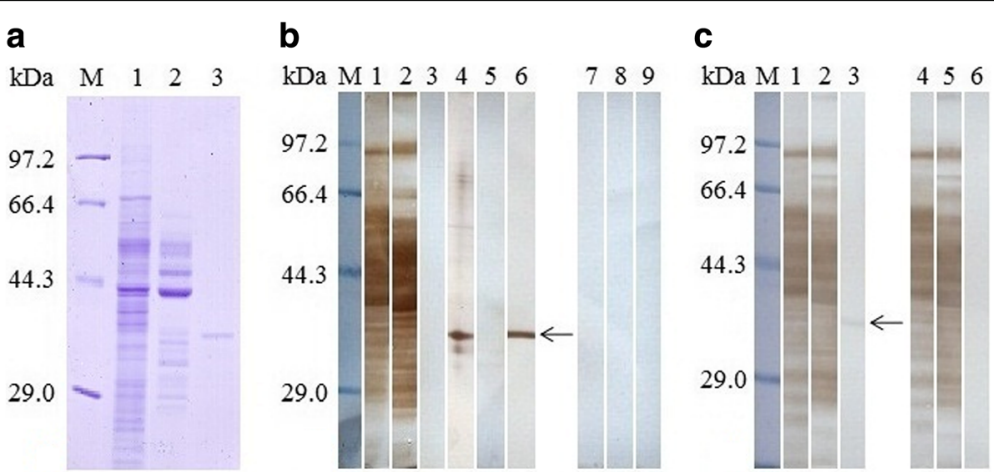

Fig. 2 Identification of the rTspGST. a SDS-PAGE analysis of T. spiralis ML crude antigen (Lane 1), ES antigen (Lane 2) and rTspGST (Lane 3). b Western blot analysis of rTspGST antigenicity. T. spiralis ML crude antigens (Lane 1) and ES antigens (Lane 2) were probed by sera of mice infected with T. spiralis at $42 \mathrm{dpi}$, but the rTsGST (Lane 3) was not probed by infection sera. The native TspGST protein in ML crude protein (Lane 4) and rTspGST (Lane 6) were probed by anti-rTspGST sera, but the ML ES antigens (Lane 5) were not probed by anti-TspGST sera. T. spiralis ML crude antigens (Lane 7), ES antigens (Lane 8) and rTspGST (Lane 9) were not probed by normal mouse sera. c Western blot analysis indicated that T. spiralis ML crude antigens (Lane 1), ES antigens (Lane 2) and rTspGST (Lane 3) were recognized by sera of mice immunized with ML crude antigens. The ML crude protein (Lane 4) and ES antigens (Lane 5) were recognized by sera of mice immunized with ML ES antigens, but rTspGST (Lane 6) were not recognized by sera of mice immunized with ML ES antigens 


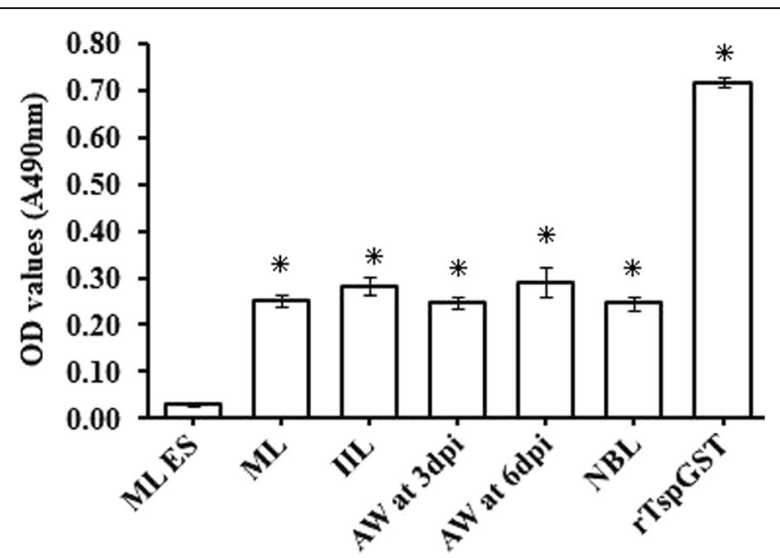

Fig. 3 Serum-specific anti-rTspGST IgG level of mice vaccinated with rTspGST determined by ELISA with crude antigens of Trichinella spiralis various stages (AW at 3 and 6 dpi, NBL, ML and IIL) and ML ES antigens. The OD values shown for each group are the mean \pm SD of the antibody levels from ten mice. Asterisks indicate statistically significant differences $\left({ }^{*} P<0.01\right)$

\section{Expression and immunolocalization of TspGST by IIFT}

The IIFT with the intact parasite revealed that green fluorescence staining by anti-rTspGST sera was seen on the surface of AW at 3 and $6 \mathrm{dpi}$ as well as NBL. In contrast, no visible staining was found on the surface of the ML and IIL (Fig. 5). After the worm tissue sections from T. spiralis different phases were probed with antirTspGST sera, the positive staining was distributed at the cuticles of the AW, ML and IIL, and the embryos within the female uterus.

\section{Humoral antibody responses elicited by vaccination with rTspGST}

Serum specific anti-rTspGST IgG, IgG1, and IgG2a at different time after vaccination were examined by ELISA

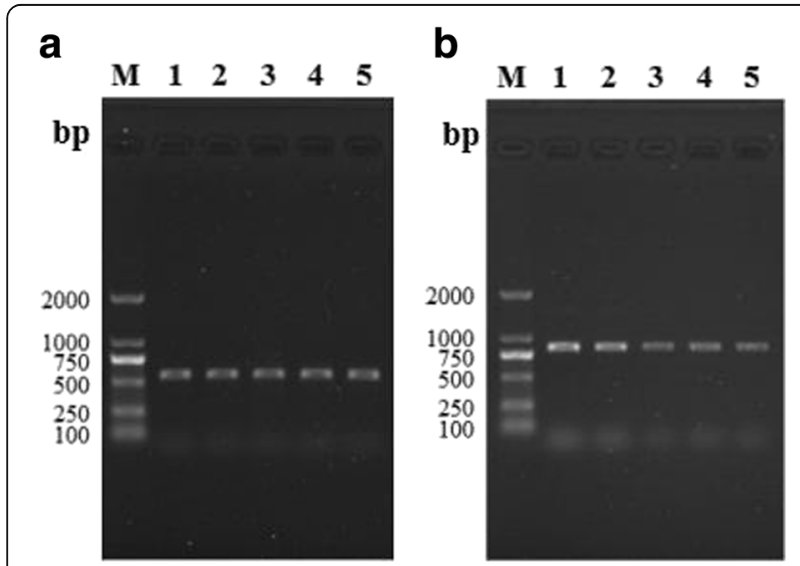

Fig. 4 RT-PCR analysis of GAPDH gene $\mathbf{a}$ and TspGST gene $\mathbf{b}$ at Trichinella spiralis various development stages. Lane M: DL2000 DNA marker; Lane 1: ML; Lane 2: IIL; Lane 3: AW at 3 dpi; Lane 4: AW at 6 dpi; Lane 5: NBL with the rTspGST. The levels of anti-rTspGST IgG in vaccinated mice were obviously elevated after the first and second vaccination and continued to rise at the end of the experiment (Fig. 6). But all of the mice injected with PBS or adjuvant did not show evidently anti-rTspGST antibody responses. Anti-rTspGST IgG subtype assay demonstrated that after the first and second vaccination, the IgG1 levels were remarkably higher than the IgG2a $\left(t_{10 \mathrm{~d}(11)}=16.432\right.$, $P<0.0001 ; t_{20 d(11)}=13.942, P<0.0001 ; t_{30 d(11)}=27.07$, $\left.P<0.0001 ; t_{40 \mathrm{~d}(11)}=27.528, P<0.0001\right)$, indicating that Th2-predominant immune response was induced in the immunized mice. However, it was obvious that the IgG2a was elicited after the second vaccination.

\section{Vaccination with rTspGST protected mice against $T$. spiralis challenge}

Immune protection against $T$. spiralis challenge infection was evaluated in mice vaccinated with rTspGST. The mice vaccinated with rTspGST exhibited a $34.38 \%$ reduction of adult worms in intestines and a $43.70 \%$ reduction of larvae in skeletal muscles (Fig. 7) compared with the mice injected with only PBS $\left(F_{\text {adults }}(2,25)=6.45\right.$, $\left.P=0.002 ; F_{\text {larvae }}(2,26)=11.555, P<0.0001\right)$. Moreover, the difference of adult $\left(t_{(16)}=2.524, P=0.023\right)$ and larval reduction $\left(t_{(19)}=4.002, P=0.001\right)$ between the vaccination group and adjuvant group was also statistically significant, whereas there was no statistical difference in the adult $(P=0.433)$ and larval worm $(P=0.558)$ burden between the alone adjuvant and PBS groups.

\section{Discussion}

Glutathione-S-transferase (GST) is a superfamily of detoxification enzymes catalyzing detoxification reactions. The previous studies demonstrated that the GSTs of Echinococcus granulosus, Fasciola hepatica, Necator americanus, Ancylostoma caninum and Seteria cervi induce the evident immune protection [33-37]. The schistosome GST28 has been identified as an effective protective antigen against Schistosoma infections [38, 39]. The vaccination of mice with the rGST26 from Fasciola gigantica showed a 77 to $84 \%$ immune protection of mice against challenge infection [40]. The recombinant GSTs from $N$. americanus had powerful capacities of binding to and detoxifying the toxic heme, which contributes to the obvious immune protection against challenge infection in hamster vaccine trials [37]. The Na-GST-1 from Necator americanus has been developed as an important hookworm vaccine, the phase 1 clinical trials were carried out in Brazilian and American volunteers, and the prominent antigen-specific IgG responses and protective immunity were produced [41, 42]. The GST seems to be an essential protein for development and survival of the parasite and could be used as a potential target for the vaccine capable of preventing parasite 


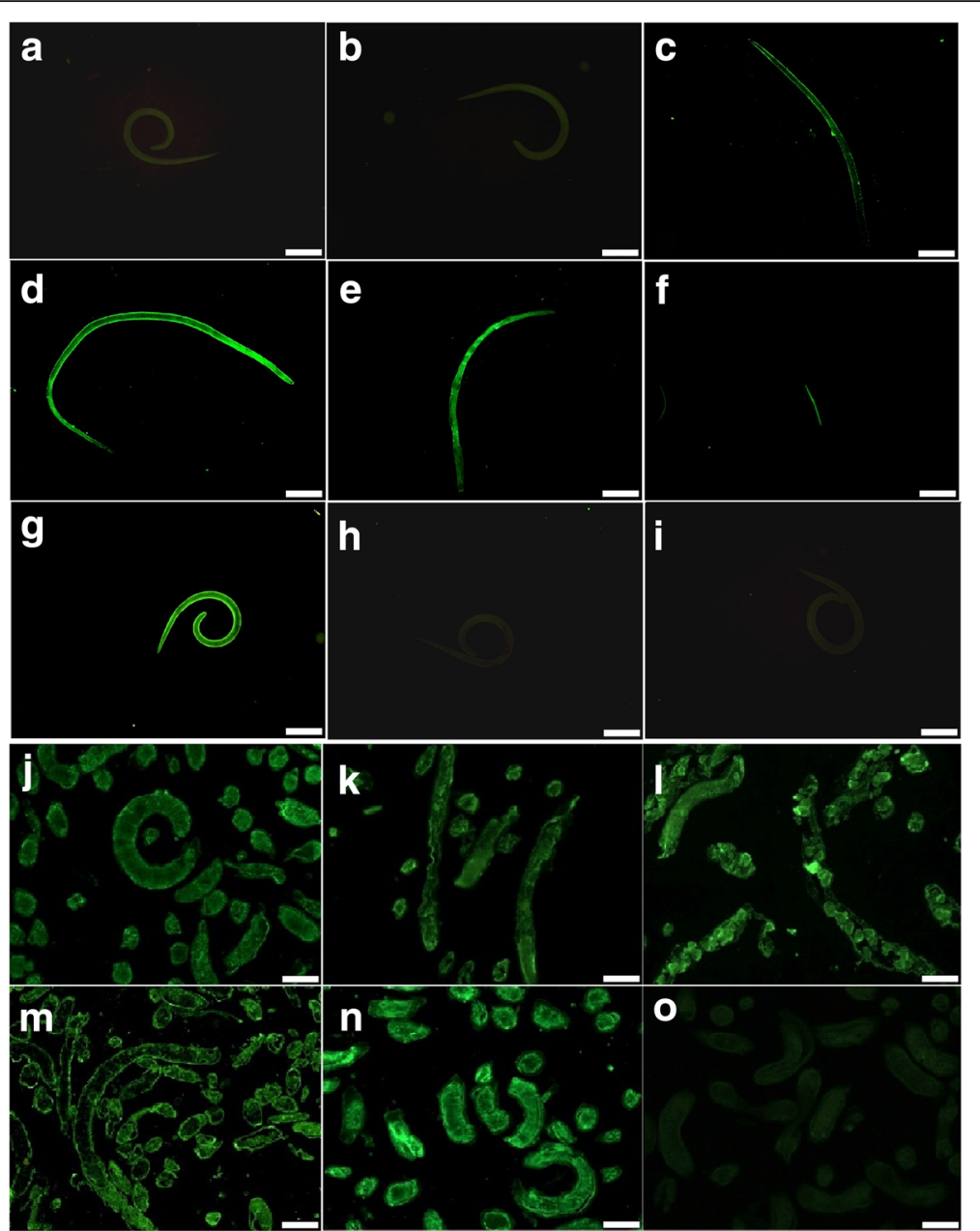

Fig. 5 Expression and immunolocalization of TspGST at Trichinella spiralis various stages. a-i The results of IIFT with the intact parasites probed by anti-rTspGST sera. The obvious fluorescent staining is observed on the surface of AW at 3 (c) and 6 dpi (d, e), and NBL (f), but not on the surface of ML (a) and IIL (b). The ML recognized by sera from T. spiralis experimentally infected mice $\mathrm{g}$ was used as a positive control; the ML incubated with normal mouse sera (h), and PBS (i) were used as negative controls. j-o Sections of intact worms (ML, IIL and AW) reacted with anti-rTspGST sera. The immunostaining is observed at the cuticle of $\mathrm{ML}(\mathbf{j}), \mathrm{ILL}(\mathbf{k})$, AW at $3(\mathbf{I})$ and $6 \mathrm{dpi}(\mathbf{m})$, especially at embryos within the female uterus. The ML recognized by sera from $T$. spiralis experimentally infected mice $n$ as positive control; the ML incubated with normal mouse sera o as negative control. Scale-bars: a-e, $\mathbf{g - i}, 200 \mu \mathrm{m} ; \mathbf{f}, \mathbf{j}-\mathbf{o}, 100 \mu \mathrm{m}$

infection. Our previous studies indicated that the vaccination of mice with a $24 \mathrm{kDa}$ rTsGST produced a $35.71 \%$ reduction of T. spiralis adults in intestines and a $38.55 \%$ reduction of larvae in muscles, the vaccination with rTsGST elicited a low immune protection against challenge infection [13].

In this study, a T. spiralis putative GST gene encoding a $30.8 \mathrm{kDa}$ protein was expressed in $E$. coli (BL21). The results revealed that the cDNA of TspGST was $840 \mathrm{bp}$ and encoded a protein of 279 amino acids, and this protein had a molecular size of $30.8 \mathrm{kDa}$ and a pI of 5.21. TspGST has only the $37 \%$ identity with TsGST at the amino acid level, suggesting that the TspGST is a significant different protein from the TsGST. The results of ELISA indicated that the immunization with the rTspGST generated the significant specific antibodies against the rTspGST, and induced the higher levels of IgG1 (Th2-predominant humoral immune responses). Anti-rTspGST antibodies recognized the native TspGST distinctly in crude proteins of AW at 3 and $6 \mathrm{dpi}, \mathrm{NBL}, \mathrm{ML}$ and IIL, but not in the ML ES proteins. Moreover, the rTspGST could be probed by sera from mice immunized with ML crude antigens, but not by sera from mice immunized with the ML ES antigens. Nonetheless, the native TspGST in the ML crude antigens was not probed with mouse infection sera, and the ML ES antigens were not probed with anti-rTspGST sera possible because the TspGST is not an ES protein and might be a cytoplasmic protein. The results suggested that the native TsGST could not be secreted and could not elicit the host to produce an obvious humoral immune 


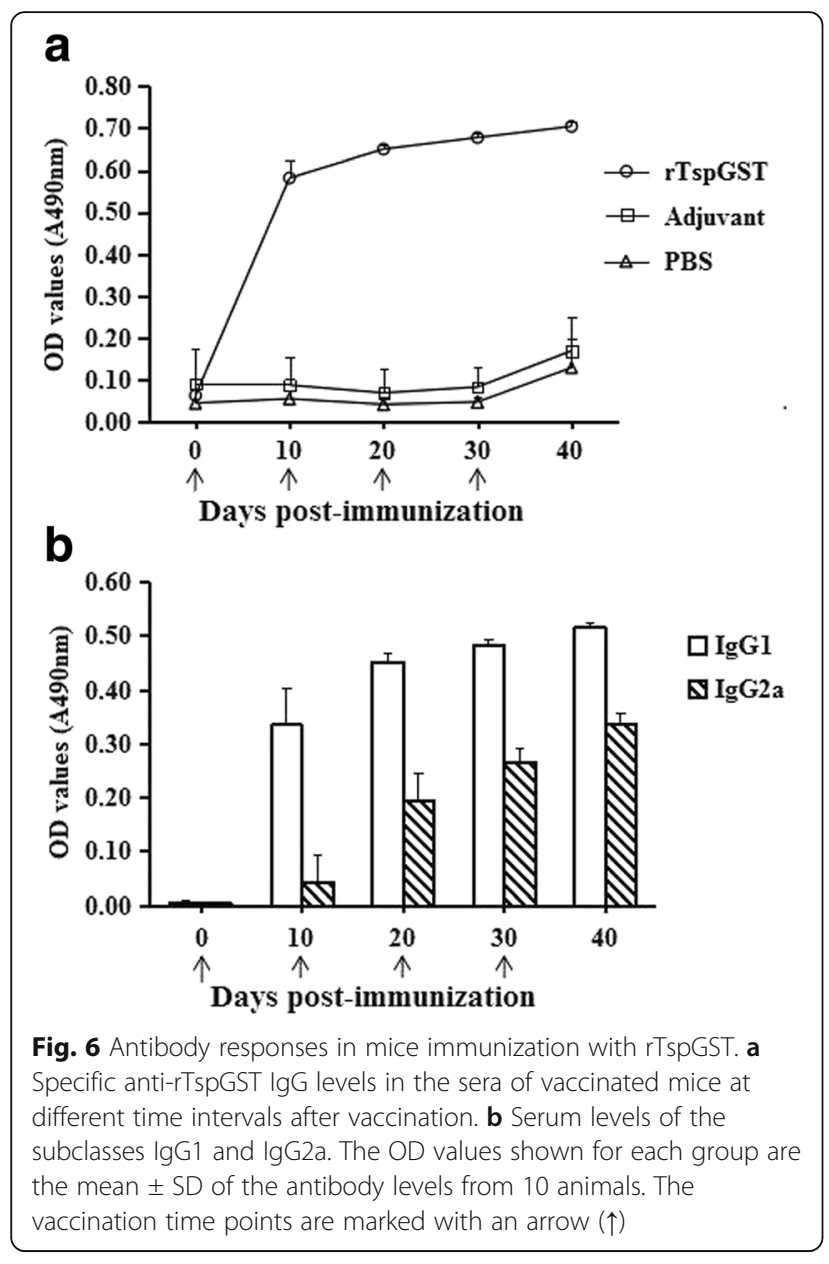

response in the process of natural Trichinella infection. Previous other studies also demonstrated the native TsGST was found in soluble somatic proteins of T. spiralis ML by Western blotting and ELISA, but not in the ES proteins of the ML $[13,43]$. The results showed that the TsGST could be one component of the somatic proteins of $T$. spiralis different stages (AW, NBL, ML and IIL), but it was not from the ES protein.

The expression level of the TspGST gene was determined by RT-PCR and IIFT. As shown in Fig. 3, TspGST mRNA is transcribed at $T$. spiralis various stages (AW, NBL, ML and IIL). The results of IIFT with anti-rTspGST sera demonstrated that the green fluorescent staining was found in all the developmental phases (principally in cuticles, and embryos within the female uterus). The results showed that TspGST was expressed at all the $T$. spiralis life-cycle stages. It is suggested that TspGST mighty be an obligatory protein for the invasion, growth, and survival in a host of this nematode.

In this experiment, the Th2-predominant immune responses were elicited by vaccination with rTspGST. After being challenged orally with $T$. spiralis $\mathrm{ML}$, the

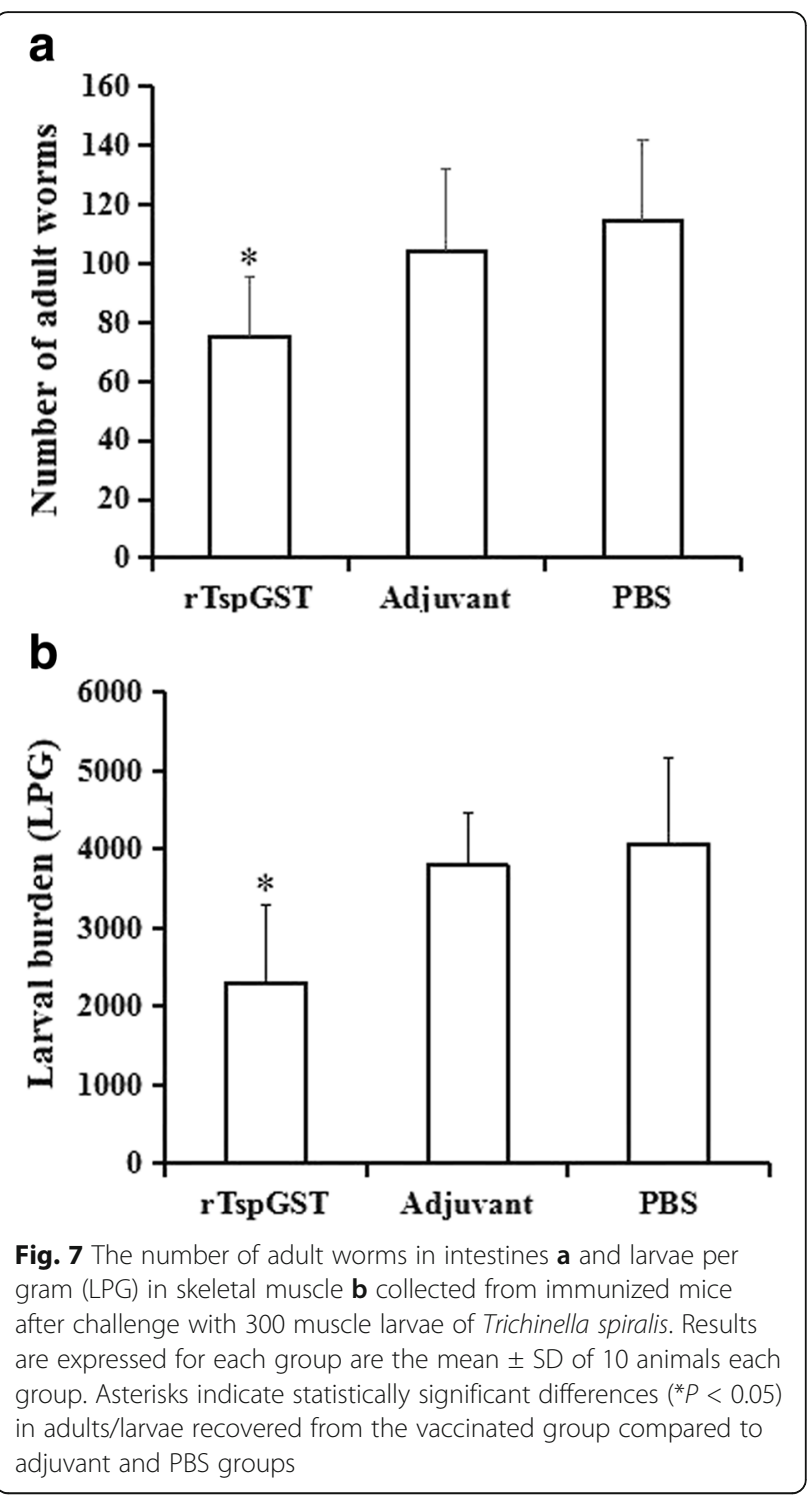

vaccination with rTspGST resulted in a $34.38 \%$ reduction of AW and a $43.70 \%$ reduction of ML. The results suggested that the partial immune protection produced by vaccination with rTspGST might be the results of a generation of anti-TspGST antibodies which neutralized the partial enzyme activity of GST $[44,45]$. The neutralization of the GST by anti-GST antibodies could decrease the survival of the filarial nematode Wuchereria bancrofti in the host [46]. The GST of Schistosoma spp. is an ES protein, the antiGST antibodies could sufficiently neutralize the enzyme activity of schistosome GST, which leads to prominent reduction of worm burdens in the vaccinated animals [44, 47]. But the TspGST is not a secretory protein, anti-rTspGST antibodies generated by immunization with rTspGST were not enough to neutralize TsGST enzyme activity in cytoplasm. The 
vaccination with $\mathrm{rTsp} G S T$ produced a partial immune protection against Trichinella infection. Hence, the oral polyvalent vaccines against the ES proteins of $T$. spiralis various developmental stages should be exploited in future experiments [8,32, 48].

\section{Conclusion}

The TsGST was expressed in all life-cycle stages of T. spiralis and distributed mainly in the cuticle of the parasitic nematode. The immunization with rTspGST elicited Th2predominant immune responses and exhibited a partial immune protection against $T$. spiralis challenge infection. The TsGST could be regarded as a potential candidate target for anti-Trichinella vaccine, but its immune protection ought to be furtherly evaluated in a swine model, and the oral polyvalent vaccines against the ES proteins of $T$. spiralis various developmental stages should be exploited in future studies.

\begin{abstract}
Abbreviations
AW: Adult worms; DAB: 3, 3'-diaminobenzidine tetrahydrochloride; dpi: Days post-infection; ES: Excretory-secretory; GAPDH: Glyceraldehyde-3-phosphate dehydrogenase; GST: Glutathione-S-transferase; hpi: Hours post-infection; IIFT: Indirect immunofluorescent test; IIL: Intestinal infective larvae; LPG: Larvae per gram; ML: Muscle larvae; NBL: Newborn larvae; OFR: Open reading frame; RT-PCR: Reverse transcription-PCR; SD: Standard deviation; SPF: Specific pathogen-free; TspGST: T. spiralis putative glutathione-Stransferase
\end{abstract}

\section{Acknowledgements}

Not applicable.

\section{Funding}

This study was supported by a grant from the National Natural Science Foundation of China (no. 81471981).

\section{Availability of data and materials}

The DNA sequence data analyzed during the present study are available in the GenBank database (accession No. XM_003373603 for TspGST).

\section{Authors' contributions}

ZQW and JC designed this study. CYL, YYS, HNR, GGS, RDL, PJ, SRL and XZ performed the experiments. CYL, ZQW, and JC wrote the manuscript. All authors read and approved the final manuscript.

\section{Ethics approval}

This study was conducted according to the National Guidelines for Experimental Animal Welfare (MOST of the People's Republic of China, 2006). All the animal experiments were authorized by the Life Science Ethics Committee, Zhengzhou University (no. 2011-016).

\section{Consent for publication}

Not applicable.

\section{Competing interests}

The authors declare that they have no competing interests.

\section{Publisher's Note}

Springer Nature remains neutral with regard to jurisdictional claims in published maps and institutional affiliations.
Received: 2 August 2017 Accepted: 17 September 2017

Published online: 29 September 2017

\section{References}

1. Murrell KD, Pozio E. Worldwide occurrence and impact of human trichinellosis, 1986-2009. Emerg Infect Dis. 2011;17:2194-202.

2. Wang ZQ, Cui J, Shen LJ. The epidemiology of animal trichinellosis in China. Vet J. 2007;173:391-8.

3. Cui J, Wang ZQ, Xu BL. The epidemiology of human trichinellosis in China during 2004-2009. Acta Trop. 2011;118:1-5.

4. Cui J, Jiang P, Liu LN, Wang ZQ. Survey of Trichinella infections in domestic pigs from northern and eastern Henan, China. Vet Parasitol. 2013;194:133-5.

5. Jiang $P$, Zhang $X$, Wang LA, Han LH, Yang M, Duan JY, et al. Survey of Trichinella infection from domestic pigs in the historical endemic areas of Henan province, central China. Parasitol Res. 2016;115:4707-9.

6. Yang J, Pan W, Sun X, Zhao X, Yuan G, Sun Q, et al. Immunoproteomic profile of Trichinella spiralis adult worm proteins recognized by early infection sera. Parasit Vectors. 2015:8:20.

7. Liu P, Cui J, Liu RD, Wang M, Jiang P, Liu LN, et al. Protective immunity against Trichinella spiralis infection induced by TsNd vaccine in mice. Parasit Vectors. 2015;8:185.

8. Wang L, Wang $X$, Bi K, Sun X, Yang J, Gu Y, et al. Oral vaccination with attenuated Salmonella typhimurium-delivered TsPmy DNA vaccine elicits protective immunity against Trichinella spiralis in BALB/C Mice. PLoS Negl Trop Dis. 2016;10:e0004952.

9. Xu J, Bai X, Wang LB, Shi HN, VAN DER Giessen JWB, Boireau P, et al. Immune responses in mice vaccinated with a DNA vaccine expressing serine protease-like protein from the new-born larval stage of Trichinella spiralis. Parasitology. 2017;144:712-9.

10. Campbell W. Trichinella and trichinosis. New York: Plenum Press; 1983. p. $51-75$

11. Liu RD, Wang ZQ, Wang L, Long SR, Ren HJ, Cui J. Analysis of differentially expressed genes of Trichinella spiralis larvae activated by bile and cultured with intestinal epithelial cells using real-time PCR. Parasitol Res. 2013;112: 4113-20.

12. Ren HJ, Cui J, Yang W, Liu RD, Wang ZQ. Identification of differentially expressed genes of Trichinella spiralis larvae after exposure to host intestine milieu. PLoS One. 2013;8:e67570.

13. Li LG, Wang ZQ, Liu RD, Yang X, Liu LN, Sun GG, et al. Trichinella spiralis: low vaccine potential of glutathione S-transferase against infections in mice. Acta Trop. 2015;146:25-32.

14. Mitreva M, Jasmer DP, Zarlenga DS, Wang Z, Abubucker S, Martin J, et al. The draft genome of the parasitic nematode Trichinella spiralis. Nat Genet. 2011:43:228-35.

15. Gamble HR, Bessonov AS, Cuperlovic K, Gajadhar AA, van Knapen F, Noeckler K, et al. International Commission on Trichinellosis: recommendations on methods for the control of Trichinella in domestic and wild animals intended for human consumption. Vet Parasitol. 2000;93:393-408.

16. Li F, Cui J, Wang ZQ, Jiang P. Factors affecting the sensitivity of artificial digestion and its optimization for inspection of Trichinella spiralis in meat. Foodborne Pathog Dis. 2010;7:879-85.

17. Liu RD, Cui J, Liu XL, Jiang P, Sun GG, Zhang X, et al. Comparative proteomic analysis of surface proteins of Trichinella spiralis muscle larvae and intestinal infective larvae. Acta Trop. 2015;150:79-86.

18. Sun GG, Wang ZQ, Liu CY, Jiang P, Liu RD, Wen H, et al. Early serodiagnosis of trichinellosis by ELISA using excretory-secretory antigens of Trichinella spiralis adult worms. Parasit Vectors. 2015;8:484.

19. Takada N, Tada T. Collection of newborn larvae of Trichinella spiralis in vitro. Jpn J Parasitol. 1988;7:251-3.

20. Wang L, Wang ZQ, Cui J. Protein changes in Trichinella spiralis muscle larvae in vitro induced by bovine bile. Vet Parasitol. 2013;194:164-7.

21. Yang W, Li LG, Liu RD, Sun GG, Liu CY, Zhang SB, et al. Molecular identification and characterization of Trichinella spiralis proteasome subunit beta type-7. Parasit Vectors. 2015;8:18.

22. Bradford MM. A rapid and sensitive method for the quantitation of microgram quantities of protein utilizing the principle of protein-dye binding. Anal Biochem. 1976;72:248-54.

23. Wang ZQ, Wang L, Cui J. Proteomic analysis of Trichinella spiralis proteins in intestinal epithelial cells after culture with their larvae by shotgun LC-MS/ MS approach. J Proteome. 2012;75:2375-83. 
24. Cui J, Ren HJ, Liu RD, Wang L, Zhang ZF, Wang ZQ. Phage-displayed specific polypeptide antigens induce significant protective immunity against Trichinella spiralis infection in BALB/c mice. Vaccine. 2013;31:1171-7.

25. Long SR, Wang ZQ, Liu RD, Liu LN, Li LG, Jiang P, et al. Molecular identification of Trichinella spiralis nudix hydrolase and its induced protective immunity against trichinellosis in BALB/c mice. Parasit Vectors. 2014;7:600.

26. Cui J, Liu RD, Wang L, Zhang $X$, Jiang P, Liu MY, et al. Proteomic analysis of surface proteins of Trichinella spiralis muscle larvae by two-dimensional gel electrophoresis and mass spectrometry. Parasit Vectors. 2013;6:355.

27. Wang B, Wang ZQ, Jin J, Ren HJ, Liu LN, Cui J. Cloning, expression and characterization of a Trichinella spiralis serine protease gene encoding a 35.5 kDa protein. Exp Parasitol. 2013;134:148-54.

28. Zhang Y, Wang Z, Li L, Cui J. Molecular characterization of Trichinella spiralis aminopeptidase and its potential as a novel vaccine candidate antigen against trichinellosis in BALB/C mice. Parasit Vectors. 2013;6:246.

29. Martinez-Gomez F, Santiago-Rosales R, Ramon B-GC. Effect of Lactobacillus casei Shirota strain intraperitoneal administration in CD1 mice on the establishment of Trichinella spiralis adult worms and on IgA anti-T. spiralis production. Vet Parasitol. 2009;162:171-5.

30. Yang Y, Zhang Z, Yang J, Chen X, Cui S, Zhu X. Oral vaccination with Ts87 DNA vaccine delivered by attenuated Salmonella typhimurium elicits a protective immune response against Trichinella spiralis larval challenge. Vaccine. 2010;28:2735-42.

31. Liu P, Wang ZQ, Liu RD, Jiang $P$, Long $S R$, Liu LN, et al. Oral vaccination of mice with Trichinella spiralis nudix hydrolase DNA vaccine delivered by attenuated Salmonella elicited protective immunity. Exp Parasitol. 2015;153:29-38.

32. Gu Y, Wei J, Yang J, Huang J, Yang $X$, Zhu X. Protective immunity against Trichinella spiralis infection induced by a multi-epitope vaccine in a murine model. PLoS One. 2013;8:e77238.

33. Morrison CA, Colin T, Sexton JL, Bowen F, Wicker J, Friedel T, et al. Protection of cattle against Fasciola hepatica infection by vaccination with glutathione S-transferase. Vaccine. 1996;14:1603-12.

34. Gupta S, Bhandari YP, Reddy MV, Harinath BC, Rathaur S. Setaria cervi: immunoprophylactic potential of glutathione-S-transferase against filarial parasite Brugia malayi. Exp Parasitol. 2005;109:252-5.

35. Zhu M, Wang $X$, Wang $H$, Wang Z, Zhao J, Wang $Y$, et al. Mechanism of protective immunity by vaccination with recombinant Echinococcus granulosus glutathione S-transferase (Chinese strain) in mice. Exp Ther Med. 2015;10:1127-32.

36. Zhan B, Liu S, Perally S, Xue J, Fujiwara R, Brophy P, et al. Biochemical characterization and vaccine potential of a heme-binding glutathione transferase from the adult hookworm Ancylostoma caninum. Infect Immun. 2005;73:6903-11.

37. Zhan B, Perally S, Brophy PM, Xue J, Goud G, Liu S, et al. Molecular cloning, biochemical characterization, and partial protective immunity of the hemebinding glutathione S-transferases from the human hookworm Necator americanus. Infect Immun. 2010;78:1552-63.

38. Capron A, Capron M, Dombrowicz D, Riveau G. Vaccine strategies against schistosomiasis: from concepts to clinical trials. Int Arch Allergy Immunol. 2001;124:9-15.

39. Rezende CM, Goes TS, Goes VS, Azevedo V, Leite MF, Goes AM. GM-CSF and TNF-alpha synergize to increase in vitro granuloma size of PBMC from humans induced by Schistosoma mansoni recombinant 28-kDa GST. Immunol Lett. 2004;95:221-8.

40. Preyavichyapugdee N, Sahaphong S, Riengrojpitak S, Grams R, Viyanant V, Sobhon P. Fasciola gigantica and Schistosoma mansoni: vaccine potential of recombinant glutathione S-transferase (rFgGST26) against infections in mice. Exp Parasitol. 2008;119:229-37.

41. Hotez PJ, Diemert D, Bacon KM, Beaumier C, Bethony JM, Bottazzi ME, et al. The human hookworm vaccine. Vaccine. 2013;31(Suppl 2):B227-32.

42. Diemert DJ, Freire J, Valente V, Fraga CG, Talles F, Grahek S, et al. Safety and immunogenicity of the Na-GST-1 hookworm vaccine in Brazilian and American adults. PLoS Negl Trop Dis. 2017;11:e0005574.

43. Rojas J, Rodriguez-Osorio M, Gomez-Garcia V. Immunological characteristics and localization of the Trichinella spiralis glutathione S-transferase. J Parasitol. 1997;83:630-5.

44. Remoue F, Rogerie F, Gallissot MC, Guyatt HL, Neyrinck JL, Diakkhate MM, et al. Sex-dependent neutralizing humoral response to Schistosoma mansoni 28GST antigen in infected human populations. J Infect Dis. 2000;181:1855-9.
45. Andure D, Pote K, Khatri V, Amdare N, Padalkar R, Reddy MV. Immunization with Wuchereria bancrofti glutathione-S-transferase elicits a mixed Th1/Th2 type of protective immune response against filarial infection in Mastomys. Indian J Clin Biochem. 2016;31:423-30.

46. Veerapathran A, Dakshinamoorthy G, Gnanasekar M, Reddy MV, Kalyanasundaram R. Evaluation of Wuchereria bancrofti GST as a vaccine candidate for lymphatic filariasis. PLoS Negl Trop Dis. 2009;3:e457.

47. Lane A, Boulanger D, Riveau G, Capron A, Wilson RA. Murine immune responses to Schistosoma haematobium and the vaccine candidate rSh28GST. Parasite Immunol. 1998;20:359-67.

48. Pompa-Mera EN, Arroyo-Matus P, Ocana-Mondragon A, Gonzalez-Bonilla CR, Yepez-Mulia L. Protective immunity against enteral stages of Trichinella spiralis elicited in mice by live attenuated Salmonella vaccine that secretes a 30-mer parasite epitope fused to the molecular adjuvant C3d-P28. Res Vet Sci. 2014;97:533-5.

\section{Submit your next manuscript to BioMed Central and we will help you at every step:}

- We accept pre-submission inquiries

- Our selector tool helps you to find the most relevant journal

- We provide round the clock customer support

- Convenient online submission

- Thorough peer review

- Inclusion in PubMed and all major indexing services

- Maximum visibility for your research

Submit your manuscript at www.biomedcentral.com/submit
C Biomed Central 